\title{
Asupan Zat Besi Berhubungan dengan Perkembangan Anak Stunting Usia 6 - 36 Bulan di Semarang
}

Maria Martiani, ${ }^{1}$ Ani Margawati, ${ }^{1}$ Maria Mexitalia, ${ }^{2}$ Farid Agung Rahmadi, ${ }^{2}$ Etika Ratna Noer,${ }^{1}$ Ahmad Syauqy ${ }^{1}$

${ }^{1}$ Departemen Ilmu Gizi, ${ }^{2}$ Bagian Ilmu Kesehatan Anak Fakultas Kedokteran Universitas Diponegoro / RSUP Dr Kariadi, Semarang

Latar belakang. Salah satu masalah gizi pada anak yaitu stunting (pendek). Salah satu faktor penyebab stunting yakni asupan zat gizi. Salah satu akibat stunting dapat mempengaruhi perkembangan anak. Ibu berperan penting pada asupan gizi serta perkembangan anak. Skrining pada usia dini berperan dalam mengetahui ada tidaknya gangguan perkembangan pada anak stunting.

Tujuan. Mengetahui hubungan asupan gizi dengan perkembangan anak stunting usia 6-36 bulan di wilayah Semarang Selatan

Metode. Desain penelitian cross sectional yang dilaksanakan di 8 puskesmas di wilayah Semarang Selatan. Data diperoleh dengan cara interview kuesioner serta pemeriksaan perkembangan dilaksanakan dengan instrumen Capute Scales pada bulan September - November 2020. Analisis multivariat regresi linier digunakan untuk mengetahui hubungan perkembangan dengan variabel dengan mengontrol variabel luar (usia, jenis kelamin, status stunting)

Hasil. Subjek berjumlah 71 anak stunting. Subjek memiliki asupan energi $(63,1 \%)$ dan zat besi $(66,2 \%)$ yang rendah. Terdapat 33,8\% anak stunting mengalami suspek gangguan perkembangan, 9,9\% gangguan komunikasi dan $11,3 \%$ suspek disabilitas intelektual. Uji multivariat regresi linier menunjukkan bahwa asupan zat besi berhubungan positif dengan perkembangan anak stunting (p 0,05).

Kesimpulan. Terdapat hubungan signifikan antara asupan zat besi dengan perkembangan anak stunting. Sari Pediatri 2021;23(2):95-102

Kata kunci: stunting, asupan gizi, karakteristik ibu, perkembangan, capute scale

\section{Iron Intake is Associated with The Development of Stunted Children Aged 6-36 Months in Semarang}

Maria Martiani, ${ }^{1}$ Ani Margawati, ${ }^{1}$ Maria Mexitalia, ${ }^{2}$ Farid Agung Rahmadi, ${ }^{2}$ Etika Ratna Noer, ${ }^{1}$ Ahmad Syauqy

Background. One of the nutritional problems in children is stunting. Nutritional intake is a factor in the occurrence of stunting. One of the consequences of stunting can affect the growth and development of children. Mothers have an important role in nutritional intake and child development. Early detection is very important to detect developmental disorders, especially in stunted children.

Objective. To determine the relationship between children's nutritional intake and the development of stunted children aged 6-36 months in South Semarang

Method. The cross-sectional research design was conducted in 8 health centers in the south semarang area. Data were obtained through questionnaire interviews and examination of the development progress of Capute Scales instrument examination results in September November 2020. Multivariate linear regression was used to evaluate the association between development and other variables with adjusting for multiple confounding variables (age, sex, and stunted status).

Result. Subjects were 71 stunting children. Subject has low energy $(63,1 \%)$ and iron intake $(66,2 \%)$. There were $33.8 \%$ of stunted children who developed suspect, 9.9\% had communication problems and $11.3 \%$ had suspect intellectual disabilities. Using multiple linear regression analysis, iron was positively significant with development stunting children $(\mathrm{p}<0,05)$.

Conclusion. There is a significant relationship between iron intake and development in stunted children. Sari Pediatri 2021;23(2):95-102

Keywords: stunting, nutrition intake, mother characteristic, development, capute scales

Alamat korespondensi: Maria Martiani. Departemen Ilmu Gizi, Fakultas Kedokteran, Universitas Diponegoro Jl. Prof. Sudarto SH Tembalang, Semarang, Jawa Tengah 50275. Email:maria_martiani@yahoo.com 
$\mathrm{K}$

esehatan dan gizi merupakan sektor penting. karena anak merupakan kelompok yang rentan dan berisiko tinggi dengan gangguan anak, yaitu stunting (pendek). Stuntingadala masala kurang gizi kronis karena asupan gizi kurang dalam jangka waktu cukup lama. ${ }^{1}$

Prevalensi balita stunting di dunia tergolong tinggi, yaitu 21,9\% pada tahun 2018. ${ }^{2}$ Berdasarkan hasil Riset Kesehatan Dasar (Riskesdas) 2018, prevalensi nasional stunting, yaitu $30,8 \%,{ }^{3}$ sedangkan prevalensi balita stunting di Kota Semarang pada tahun 2018 sebesar 29,73\%. ${ }^{3}$ Jika dilihat dari hasil Penilaian Status Gizi (PSG) tahun 2017dengan prevalensi stunting sebesar 21 $\%$ maka hal ini menunjukkan ada tren kenaikan stunting di kota Semarang dari tahun ke tahun. ${ }^{4}$

Menurut World Health Organization (WHO), stunting dapat menyebabkan masalah jangka pendek dan jangka panjang. Masalah jangka pendek, antara lain, peningkatan morbiditas dan mortalitas, penurunan perkembangan kognitif, perkembangan motorik, dan perkembangan bahasa, serta peningkatan biaya kesehatan. ${ }^{5}$ Sementara konsekuensi jangka Panjang, antara lain, penurunan perawakan dewasa, peningkatan obesitas yang terkait komorbiditas, penurunan kemampuan belajar di sekolah, penurunan kapasitas belajar dan pencapaian potensi, serta penurunan kapasitas bekerja dan produktifitas kerja. ${ }^{5}$ Gangguan pertumbuhan dan perkembangan pada anak dipengaruhi oleh beberapa hal, salah satunya adalah kekurangan nutrisi. Insiden stunting tidak terlepas dari kekurangan asupan zat gizi makro, seperti energi, karbohidrat, protein, lemak serta zat gizi mikro, seperti zat besi pada balita. Asupan zat gizi yang berperan penting dalam perkembangan otak, antara lain, energi, protein, jenis lemak tertentu serta zat besi. ${ }^{6}$ Anak dengan berat badan lahir rendah (BBLR) dan mengalami gagal tumbuh pasca kelahiran akibat defisiensi energi atau protein, defisiensi mikronutrien, atau keduanya akan berisiko memiliki perkembangan yang buruk. ${ }^{7}$ Perkembangan anak tidak hanya dipengaruhi oleh asupan gizi, tetapi juga faktor karakteristik ibu. Peran ibu dalam mengasuh anak merupakan faktor penting dalam memengaruhi tumbuh kembang anak. Tingkat pendidikan berperan penting. Ibu yang berpendidikan akan memiliki kualitas pola asuh serta pemberian stimulasi pada anak yang berbeda dibandingkan dengan yang berpendidikan rendah. Tingkat pendidikan berpengaruh dalam kemampuan ibu dalam menyerap informasi dan pengetahuan mengenai kesehatan dan gizi. ${ }^{8} \mathrm{Ozkan} \mathrm{dkk}^{9}$ menyatakan bahwa sosial ekonomi merupakan faktor risiko yang kuat terhadap perkembangan terlambat pada anak usia 3 bulan sampai dengan lima tahun.

Selain itu, Permatasari ${ }^{10}$ dan Perignon dkk, ${ }^{11}$ mengatakan bahwa terdapat perbedaan perkembangan kognitif yang signifikan antara anak stunting dengan tidak stunting. Berdasarkan data operasi timbang Kota Semarang tahun 2019, diketahui bahwa wilayah Semarang Selatan memiliki 766 balita dan belum adanya penelitian mengenai asupan gizi serta perkembangan anak stunting di wilayah Semarang Selatan. Berlatar belakang masalah, peneliti ingin melihat hubungan antara asupan zat gizi, karakteristik ibu dengan perkembangan anak stunting usia 6-36 bulan di Semarang.

\section{Metode}

Penelitian ini merupakan penelitian observasional dengan rancangan cross sectional, dilakukan pada 71 anak usia 6-36 bulan di puskesmas wilayah kerja Semarang Selatan, selama September-November 2020. Pengambilan sampel di lakukan secara consecutive sampling. Kriteria inklusi adalah balita dengan usia 6-36 bulan, termasuk dalam kategori balita stunting (Tinggi Badan/Umur <-2 Standar Deviasi) berdasarkan WHO Child Growth Standards, bersedia mengikuti penelitian dengan mendapatkan persetujuan dari orang tua (informed consent). Kriteria eksklusi adalah kelainan kongenital atau cacat fisik, menderita penyakit kronis yang mengganggu metabolisme tubuh. Skrining pemeriksaan perkembangan dilakukan dengan metode Capute Scales oleh dokter spesialis anak serta dilanjutkan dengan wawancara kuesioner serta food recall $3 \times 24$ jam oleh enumerator. Penelitian ini telah mendapat persetujuan etik dari Komisi Etik Fakultas Kedokteran Universitas Sultan Agung Semarang No. 313/IX/2020/Komisi Bioetik

Pendidikan ibu dikategorikan dengan rendah ( $\leq$ SMP) tinggi ( $\geq$ SMA). Pekerjaan ibu dikategorikan menjadi tidak bekerja apabila sebagai ibu rumah tangga dan bekerja apabila setiap hari bekerja tetap di luar rumah. Pendapatan keluarga di golongkan menjadi rendah (< UMR Kota Semarang) dan Cukup ( $\geq$ UMR Kota Semarang). Asupan zat gizi dianalisis menggunakan software Nutrisurvey 2007 kemudian di kategorikan 
menjadi asupan rendah jika $<80 \%$ AKG (Angka Kecukupan Gizi) dan cukup jika $\geq 80 \%$ AKG. Hasil dari pemeriksaan perkembangan dikategorikan menjadi perkembangan normal (jika full-scale developmental quotient / FSDQ $>85$, serta developmental quotient / DQ $>85$ pada kemampuan bahasa dan visuo motorik), suspek (pada salah satu atau kedua aspek skor DQ 7585), suspek disabilitas intelektual (DQ pada ke dua apek $<75$ ), serta gangguan komunikasi (DQ bahasa $<85$, DQ visual motor $>85) .^{12}$
Data yang di peroleh kemudian dianalisis secara statistik menggunakan program komputer. Analisis univariat untuk melihat distribusi frekuensi data subjek dan orang tua subjek. Data kontinu disajikan dalam bentuk mean $\pm S D$ untuk data yang terdistribusi normal dan median (minimum-maksimum) untuk data yang tidak terdistribusi normal. Sementara data kategorik disajikan dalam bentuk n (\%). Tes distribusi normalitas di ukur menggunakan tes Kolmogorov-smirnov dengan nilai $\rho$ value $>0,05$. Analisis bivariat menggunakan uji

Tabel 1. Distribusi frekuensi karakteristik subjek dan ibu

\begin{tabular}{|c|c|c|}
\hline \multirow{2}{*}{ Variabel } & \multicolumn{2}{|c|}{ Seluruh subjek } \\
\hline & $\mathrm{n}(\%)$ & Nilai \\
\hline Usia & & $21,97 \pm 7,45$ \\
\hline \multicolumn{3}{|l|}{ Jenis kelamin anak (\%) } \\
\hline Laki-laki & $37(53,2)$ & \\
\hline Perempuan & $34(47,9)$ & \\
\hline \multicolumn{3}{|l|}{ Status stunting (\%) } \\
\hline Severe stunting & $14(19,7)$ & \\
\hline Stunting & $57(80,3)$ & \\
\hline Asupan energi (\%) & & $938 \pm 387,27$ \\
\hline Rendah & $45(63,1)$ & \\
\hline Cukup & $26(36,6)$ & \\
\hline Asupan protein (\%) & & $33,31 \pm 15,13$ \\
\hline Rendah & $8(11,3)$ & \\
\hline Cukup & $63(52,1)$ & \\
\hline Asupan lemak (\%) & & $39,57 \pm 20,51$ \\
\hline Rendah & $33(47,9)$ & \\
\hline Cukup & $37(52,1)$ & \\
\hline Asupan zat besi (\%) & & $4,9(1,13-23,30)^{* *}$ \\
\hline Rendah & $47(66,2)$ & \\
\hline Cukup & $24(33,8)$ & \\
\hline \multicolumn{3}{|l|}{ Tingkat pendidikan ibu (\%) } \\
\hline Rendah & $21(21,9)$ & \\
\hline Tinggi & $50(70,4)$ & \\
\hline \multicolumn{3}{|l|}{ Pekerjaan ibu (\%) } \\
\hline Tidak bekerja & $47(66,2)$ & \\
\hline Bekerja & $24(33,8)$ & \\
\hline \multicolumn{3}{|l|}{ Penghasilan keluarga (\%) } \\
\hline Rendah & $33(46,5)$ & \\
\hline Cukup & $38(53,5)$ & \\
\hline Perkembangan (\%) & & $87,9145 \pm 14,92$ \\
\hline Normal & $32(45,1)$ & \\
\hline Suspek & $24(33,8)$ & \\
\hline Gangguan komunikasi & $7(9,9)$ & \\
\hline Suspek disabilitas intelektual & $8(11,3)$ & \\
\hline
\end{tabular}


Maria Martiani dkk: Asupan zat besi berhubungan dengan perkembangan anak stunting usia 6 - 36 bulan

Tabel 2. Analisis bivariat variabel dengan perkembangan usia $6-36$ bulan $(n=71)$

\begin{tabular}{|c|c|c|c|c|c|c|c|c|c|}
\hline \multirow{3}{*}{ Variabel } & \multicolumn{8}{|c|}{ Perkembangan } & \multirow{3}{*}{$\mathrm{p}^{*}$} \\
\hline & \multicolumn{2}{|c|}{ Normal } & \multicolumn{2}{|c|}{ Suspek } & \multicolumn{2}{|c|}{$\begin{array}{c}\text { Gangguan } \\
\text { komunikasi }\end{array}$} & \multicolumn{2}{|c|}{$\begin{array}{c}\text { Suspek disabilitas } \\
\text { intektual }\end{array}$} & \\
\hline & $\mathrm{n}$ & $\%$ & $\mathrm{n}$ & $\%$ & $\mathrm{n}$ & $\%$ & $\mathrm{n}$ & $\%$ & \\
\hline Usia (bulan) & 16 & 22,5 & 12 & 16,9 & 2 & 2,8 & 2 & 2,8 & \multirow{2}{*}{0,21} \\
\hline $\begin{array}{l}6-21 \\
22-36\end{array}$ & 16 & 22,5 & 12 & 16,9 & 5 & 7 & 6 & 8,5 & \\
\hline \multicolumn{10}{|l|}{ Jenis kelamin } \\
\hline Laki-laki & 11 & 15,5 & 16 & 22,5 & 3 & 4,2 & 3 & 4,2 & \multirow[t]{2}{*}{0,75} \\
\hline Perempuan & 21 & 29,6 & 8 & 33,8 & 3 & 5,6 & 5 & 7 & \\
\hline \multicolumn{10}{|l|}{ Status stunting } \\
\hline Severe stunting & 6 & 8,5 & 5 & 7 & 1 & 1,4 & 2 & 2,8 & \multirow[t]{2}{*}{0,84} \\
\hline Stunting & 25 & 36,6 & 19 & 26,8 & 6 & 8,5 & 6 & 8,5 & \\
\hline \multicolumn{10}{|l|}{ Kecukupan energi } \\
\hline Kurang & 23 & 51,1 & 15 & 33,3 & 3 & 6,7 & 4 & 8,9 & \multirow[t]{2}{*}{0,11} \\
\hline Cukup & 9 & 34,6 & 9 & 34,6 & 4 & 15,4 & 4 & 15,4 & \\
\hline \multicolumn{10}{|l|}{ Asupan protein } \\
\hline Kurang & 4 & 50 & 3 & 37,5 & 1 & 12,5 & 0 & 0 & \multirow[t]{2}{*}{0,57} \\
\hline Cukup & 28 & 44,4 & 21 & 33,3 & 6 & 9,5 & 8 & 12,7 & \\
\hline \multicolumn{10}{|l|}{ Asupan lemak } \\
\hline Kurang & 16 & 47,1 & 11 & 32.4 & 3 & 8,8 & 4 & 11,8 & \multirow[t]{2}{*}{0,80} \\
\hline Cukup & 16 & 43,2 & 13 & 35,1 & 4 & 10,8 & 4 & 10,8 & \\
\hline \multicolumn{10}{|l|}{ Asupan zat besi } \\
\hline Kurang & 25 & 53,2 & 14 & 29,8 & 3 & 6,4 & 5 & 10,6 & \multirow[t]{2}{*}{0,03} \\
\hline Cukup & 7 & 29,2 & 10 & 41,7 & 4 & 16,7 & 3 & 12,5 & \\
\hline \multicolumn{10}{|l|}{ Pendidikan ibu } \\
\hline Rendah & 8 & 38,1 & 9 & 42,9 & 2 & 9,5 & 2 & 9,5 & \multirow[t]{2}{*}{0,67} \\
\hline Tinggi & 24 & 48 & 15 & 30 & 5 & 10 & 6 & 12 & \\
\hline \multicolumn{10}{|l|}{ Pekerjaan ibu } \\
\hline Tidak bekerja & 22 & 46,8 & 18 & 38,3 & 2 & 4,3 & 5 & 10,6 & \multirow[t]{2}{*}{0,35} \\
\hline Bekerja & 10 & 41,7 & 6 & 25 & 5 & 20,8 & 3 & 12,5 & \\
\hline \multicolumn{10}{|c|}{ Pendapatan keluarga } \\
\hline Rendah & 18 & 54,5 & 8 & 24,2 & 2 & 6,1 & 5 & 15,2 & \multirow[t]{2}{*}{0,33} \\
\hline Cukup & 14 & 36,8 & 16 & 42,1 & 5 & 13,2 & 3 & 7,9 & \\
\hline
\end{tabular}

Mann Whitney dengan $\mathrm{p}<0,05$ serta analisis multivariat dengan menggunakan uji regresi linier dengan $\mathrm{p}<0,05$.

\section{Hasil}

Jumlah balita adalah 71 balita. Pada Tabel 1 tercantum distribusi subjek penelitian dengan jenis kelamin laki laki sebesar 52,1\%. Terdapat 14 anak mempunyai status gizi severe stunting (19,7\%). Pada karakteristik responden (orang tua), tingkat pendidikan yang tinggi ibu $(70,4 \%)$. Sebagian besar ibu bekerja sebagai IRT
$(66,2 \%)$ dengan pendapatan total keluarga cukup sebesar 38 keluarga (53,5\%). Diketahui bahwa sebagian besar subjek penelitian memiliki asupan yang rendah jika dibandingkan dengan AKG yang meliputi asupan energi $(63,1 \%)$, karbohidrat (80,3\%), dan zat besi total $(66,2 \%)$. Sementara untuk asupan protein total $(88,7 \%)$ dan lemak $(52,1 \%)$ sebagian besar responden memiliki asupan cukup.

Pada aspek perkembangan anak stunting, 24 anak memiliki perkembangan total dalam kategori suspek, 7 anak mengalami gangguan komunikasi dan 8 anak suspek disabilitas intelektual. 
Maria Martiani dkk: Asupan zat besi berhubungan dengan perkembangan anak stunting usia 6 - 36 bulan

Tabel 3. Regresi linier hubungan antara variabel dengan perkembangan

\begin{tabular}{|c|c|c|}
\hline \multirow{2}{*}{ Variabel } & \multicolumn{2}{|c|}{ Perkembangan } \\
\hline & Model 1* & Model 2* \\
\hline \multirow[t]{3}{*}{ Kecukupan energi } & 87,54 & 87,69 \\
\hline & $0,46(-8,48-9,40)$ & $0,45(-8,58-9,50)$ \\
\hline & $0,91^{* *}$ & $0,92^{* *}$ \\
\hline \multirow[t]{3}{*}{ Asupan protein } & 87,44 & 87,94 \\
\hline & $4,13(-7,08-15,34)$ & $0,88(-11,05-12,82)$ \\
\hline & $0,46^{* *}$ & $0,88^{* *}$ \\
\hline \multirow[t]{3}{*}{ Asupan lemak } & 86,48 & 87,07 \\
\hline & $2,99(-4,09-10,08)$ & $1,42(-5,86-8,71)$ \\
\hline & $0,40^{* *}$ & $0,69^{* *}$ \\
\hline \multirow[t]{3}{*}{ Asupan zat besi } & 80,94 & 87,24 \\
\hline & $10,53(3,44-17,62)$ & $14,32(5,05-23,6)$ \\
\hline & $0,00^{* *}$ & $0,01^{* *}$ \\
\hline \multirow[t]{3}{*}{ Pendidikan ibu } & 89,17 & 88,22 \\
\hline & $-4,26(-12,00-3,46)$ & $-1,92(-10,16-6,31)$ \\
\hline & $0,27^{* *}$ & $0,64^{* *}$ \\
\hline \multirow[t]{3}{*}{ Pekerjaan ibu } & 89,42 & 88,33 \\
\hline & $-4,46(-11,91-2,98)$ & $-4,73(-12,35-2,89)$ \\
\hline & $0,23^{* *}$ & $0,22^{* *}$ \\
\hline \multirow[t]{3}{*}{ Pendapatan keluarga } & 87,65 & 87,92 \\
\hline & $0,55(-6,57-7,69)$ & $1,49(-5,72-8,71)$ \\
\hline & $0,87^{* *}$ & $0,68^{* *}$ \\
\hline
\end{tabular}

Keterangan : data adalah constant, unstandardized coefficient B (IK 95\%) * multivariat regresi linear tanpa kontrol variabel perancu; ${ }^{* *}$ Multivariat regresi linier dengan kontrol variabel usia, jenis kelamin dan status stunting

Hasil analisis bivariat diketahui bahwa tidak terdapat hubungan yang signifikan antara asupan energi, protein, lemak, pendidikan ibu, pekerjaan ibu dan penghasilan keluarga dengan perkembangan balita stunting $(\mathrm{p}>0,05)$. Namun, terdapat hubungan signifikan antara asupan zat besi dengan perkembangan balita stunting $(\mathrm{p}<0,05)$ (Tabel 2).

Pada analisis multivariat regresi linier (Tabel 3) diketahui bahwa asupan zat besi berhubungan positif dengan perkembangan anak $(\mathrm{p}<0,05)$.

\section{Pembahasan}

Stunting atau pendek didefinisikan sebagai tinggi menurut usia yang kurang dari -2 standar deviasi WHO. ${ }^{2}$ Faktor risiko terjadinya stunting dan severe stunting, antara lain, usia anak, jenis kelamin laki-laki, pendidikan ibu, ${ }^{13}$ rendahnya pendapatan keluarga. ${ }^{14}$

Pada penelitian ini, stunting didominasi oleh laki laki $(53,5 \%)$. Hal ini sesuai dengan penelitian lain yang menyatakan balita berjenis laki laki lebih banyak mengalami stunting. ${ }^{13,15} \mathrm{Hal}$ ini dapat di sebabkan anak laki laki cenderung lebih aktif dan menghabiskan banyak energi untuk bergerak.

Penelitian ini juga menunjukkan bahwa sebagian ibu pendidikan tinggi, tidak bekerja (IRT) serta memiliki pendapatan keluarga yang cukup. Hal ini bertentangan dengan penelitian pada anak usia 0,5-12 tahun di Indonesia yang menunjukkan bahwa pendidikan orang tua dan sosial ekonomi keluarga berhubungan dengan kejadian stunting. ${ }^{16}$ Keluarga dengan penghasilan rendah lebih berisiko mengalami kejadian stunting karena keluarga dengan pendapatan cukup akan mampu 
membeli dan menyediakan makanan yang sehat dan berkualitas. ${ }^{14,17}$ Selain itu, orang tua yang memiliki tingkat pendidikan yang tinggi tidak selalu mempunyai pengetahuan gizi yang cukup baik. ${ }^{18}$

Pendidikan ibu serta penghasilan keluarga pada penelitian ini tidak terdapat hubungan signifikan dengan perkembangan balita stunting. Hasil tersebut tidak sejalan dengan Celikkiran $\mathrm{dkk}^{19}$ yang menyebutkan bahwa tingkat pendidikan orang tua berhubungan dengan perkembangan yang tidak normal. Oleh karena itu, pendidikan ibu menjadi faktor penting pertimbangan karena ibu dengan tingkat pendidikan yang rendah akan memiliki kesulitan dalam menstimulasi anak. Selain itu, semakin rendah penghasilan keluarga semakin tinggi perkembangan anak yang tidak normal. ${ }^{19}$ Hasil yang sama juga dilaporkan oleh Ozkan dkk ${ }^{9}$ bahwa pendidikan orang tua, baik ayah maupun ibu, berhubungan kuat dengan hasil perkembangan abnormal pada anak usia 3 bulan sampai 5 tahun. Tingkat pendidikan berperan dalam proses tumbuh kembang anak. Pola asuh serta pemberian stimulasi pada anak dengan ibu berpendidikan tinggi akan lebih berkualitas dibandingkan dengan ibu berpendidikan rendah. Tingkat pendidikan berpengaruh dalam kemampuan ibu dalam menyerap informasi dan pengetahuan mengenai kesehatan dan gizi. ${ }^{20}$

Pendapatan keluarga tidak berhubungan antara dengan perkembangan anak stunting. Penelitian di Turki dilaporkan bahwa sosial ekonomi merupakan faktor risiko yang kuat terhadap keterlambatan perkembangan pada anak usia 3 bulan sampai dengan lima tahun yang diukur dengan Denver II. ${ }^{9}$ Hasil ini sejalan dengan penelitian Susanty ${ }^{21}$ yang melaporkan hasil serupa terhadap hubungan antara pendapatan keluarga dengan perkembangan balita pada aspek motorik. Hal tersebut dapat disebabkan karena rerata pendapatan bukan merupakan faktor langsung yang dapat memengaruhi perkembangan anak. Menurut Soetjiningsih ${ }^{8}$, penghasilan keluarga yang cukup diharapkan dapat menyediakan kebutuhan primer maupun sekunder untuk anak sehingga dapat mendukung tumbuh kembang anak.

Sebagian besar anak stunting memiliki perkembangan yang tidak baik. Cusick $\mathrm{dkk}^{7}$ melaporkan bahwa status gizi stunted memengaruhi perkembangan selsel otak sehingga menganggu perkembangan anak. Perkembangan otak anak berhubungan dengan konsumsi zat gizi yang sebagian besar terjadi pada seribu hari kehidupan. Kekurangan zat gizi setelah
1000 hari kehidupan atau usia dua tahun maka akan menghambat perkembangan anak. Sel saraf otak terus meningkat hingga usia 5 tahun karena pada usia tersebut besar otak anak telah 90\% mendekati besar otak orang dewasa. Oleh karena itu, sangat penting untuk menjaga asupan gizi yang tepat selama kehamilan hingga usia anak lima tahun. Asupan gizi berperan penting dalam perkembangan otak. ${ }^{22}$

Insiden stunting tidak terlepas dari asupan zat gizi makro dan mikro pada balita. Kekurangan zat gizi pada anak stunting dapat menyebabkan perkembangan motorik yang buruk sehingga tingkat aktivitas rendah, hal ini juga akan mengakibatkan sikap apatis dan kurang berminat pada lingkungan. ${ }^{23}$ Subjek pada penelitian ini sebagian besar memiliki riwayat asupan energi dan zat besi yang rendah. Adani ${ }^{22}$ melaporkan bahwa balita stunting memiliki asupan energi yang kurang. Anak dengan asupan energi kurang berisiko 1,24 kali lebih tinggi mengalami stunting dibandingkan dengan anak yang memiliki asupan energi cukup. ${ }^{24}$ Asupan protein penelitian ini menunjukkan hasil yang baik. Hasil ini sejalan dengan penelitian Adani ${ }^{22}$ di Surabaya yang melaporkan hasil bahwa anak stunting memiliki asupan protein yang cukup. Asupan protein yang tinggi disebabkan karena sebagian besar subjek penelitian mengonsumsi susu formula dengan frekuensi 2-5 kali sehari.

Asupan lemak menunjukkan sebagian besar subjek penelitian memiliki asupan lemak yang baik. Asupan tersebut berasal dari konsumsi susu. Namun, hasil berbeda dilaporkan Azmy Di Kabupaten Bangkalan, Azmy melaporkan bahwa tingkat asupan lemak balita tidak stunting (usia 24-59 bulan) lebih baik daripada balita stunting. Di samping itu, kekurangan konsumsi karbohidrat juga berisiko 1,7 kali lebih besar mengalami stunting. ${ }^{25}$

Mayoritas subjek penelitian memiliki asupan zat besi yang rendah. Zat besi $(\mathrm{Fe})$ merupakan mikronutrien yang berperan dalam perkembangan psiko-motorik anak. Hasil ini sejalan dengan penelitian lain yang mel paorkan bahwa anak stunting memiliki asupan zat besi yang rendah. ${ }^{22,26}$

Hasil studi Sumedi dan Sanjaya ${ }^{27}$ diketahui bahwa asupan zat besi pada anak usia 6-23 bulan di Indonesia sudah lebih tinggi (60,3\% AKG). Zat besi diperlukan untuk pertumbuhan pada usia bayi sampai remaja. Selain itu, zat besi berfungi untuk mengganti zat darah yang hilang serta meningkatkan massa sel darah. ${ }^{28}$ 
Riset yang dilakukan oleh South-East Asian Nutrition Survey SEANUTS tahun 2013 mengenai pola makan balita usia 6-23 bulan menyimpulkan bahwa sebagian besar balita jarang atau tidak pernah mengonsumsi daging, ikan, dan unggas. ${ }^{27}$ Pola asupan seperti ini dapat menyebabkan tidak terpenuhinya kebutuhan zat besi tubuh. Kekurangan zat besi dapat menyebabkan gangguan gangguan perkembangan saraf auditori. $^{29}$

Zat besi berperan dalam sintesis monoamine, metabolisme energi dalam neurondan sel glia, mielinisasi, sistem neurotransmitter serta metabolisme dopamine. Salah satu gejala akibat kekurangan zat besi di jaringan tubuh, yaitu adanya kelainan tingkah laku dan kelainan fungsi kognitif. Kadar zat besi rendah dalam darah dapat mengakibatkan sintesis hemoglobin terhambat. Kadar hemoglobin dalam darah sejalan dengan kecepatan perkembangan otak anak.

Hasil analisis multivariat menunjukkan bahwa asupan zat besi merupakan faktor prediksi perkembangan. Hal ini sejalan dengan penelitian pada anak sekolah yang menunjukkan bahwa rendahnya status besi berhubungan dengan rendahnya kemampuan kognitif anak. ${ }^{11}$ Menurut Lunn, ${ }^{30}$ peran traktus gastrointestinal, terutama pada mukosa usus halus, adalah sebagai barrier antara tubuh dan lingkungan. Lapisan sel tunggal, eritrosit, dan lapisan mukosa harus bisa menyerap nutrisi, tetapi juga harus bisa bertindak sebagai penghalang untuk mencegah toksin dan mikroorganisme dari lingkungan untuk mendapatkan akses ke tubuh. Kerusakan mukosa yang disebabkan oleh lingkungan dapat membahayakan penyerapan dan dapat menghalangi nutrisi ke dalam tubuh yang dapat menyebabkan gangguan pertumbuhan dan perkembangan.

Berdasarkan rekomendasi WHO, asupan zat besi dapat ditingkatkan dengan cara fortifikasi makanan dengan zat besi, memberikan formula tinggi zat besi ketika ASI sudah tidak mencukupi, mencegah pemberian susu sapi / formula sebelum berumur 1 tahun, memperbanyak asupan makan tinggi zat besi, suplementasi besi selama hamil, dan suplementasi besi jika defisiensi besi. ${ }^{31}$

Keterbatasan penelitian ini, di antaranya desain penelitian cross sectional, serta instrumen food recall 24 hours sehingga tidak bisa menggambarkan riwayat asupan makannya. Hal tersebut karena stunting adalah suatu kondisi kekurangan asupan zat gizi yang terjadi pada masa lampau dan dalam waktu yang lama.

\section{Kesimpulan}

Penelitian ini menyimpulkan bahwa asupan zat besi berhubungan signifikan serta merupakan faktor predominan terhadap perkembangan anak stunting usia $6-36$ bulan.

\section{Daftar pustaka}

1. Black MM, Walker SP, Fernald LCH, dkk. Advancing early childhood development : from science to scale 1 : Early childhood development coming of age : science through the life course. Lancet 2017;389:77-90.

2. World Health Organization. Child stunting [Internet]. 2019 [cited 2020 Jun 20]. Didapat dari: https://apps.who.int/gho/ datalnode.sdg.2-2-viz-1?lang=en

3. Tim Riskesdas. Laporan Nasional Riskesdas 2018. Riset Kesehatan Dasar 2018. Jakarta; Riskesdas; 2019.

4. Kementerian Kesehatan RI. Hasil Pemantauan status gizi (PSG) tahun 2017. Masyarakat DG, penyunting. Buku saku pemantauan status gizi tahun 2017. Jakarta: Kementerian Kesehatan RI; 2018.

5. World Health Organization. Childhood stunting: context, causes and consequences - WHO conceptual framework. WHO; 2013.

6. Georgieff MK. Nutrition and the developing brain: Nutrient priorities and measurement. Am J Clin Nutr 2007;85:614-20.

7. Cusick SE, Georgieff MK. The role of nutrition in brain development : The golden opportunity of the "first 1000 days". J Pediatr 2016;175:16-21.

8. Soetjiningsih. Tumbuh kembang anak. Edisi pertama. Ranuh ING, penyunting. Jakarta: Penerbit Buku Kedokteran EGC; 1995.

9. Ozkan M, Senel S, Arslan EA, Karacan CD. The socioeconomic and biological risk factors for developmental delay in early childhood. Eur J Pediatr 2012;171:1815-21.

10. Permatasari DF, Sumarmi S. Perbedaan panjang badan lahir, riwayat penyakit, infeksi, dan perkembangan balita stunting dan non stunting. J Berk Epidemiol 2018;6:182-91.

11. Perignon M, Fiorentino M, Kuong K, dkk. Stunting, poor iron status and parasite infection are significant risk factors for lower cognitive performance in cambodian school-aged children. PLoS One 2014;9:1-11.

12. Dhamayanti M, Herlina M. Skrining gangguan kognitif dan bahasa dengan menggunakan capute scales (cognitive adaptive test / clinical linguistic $\&$ auditory milestone scale-cat/clams). Sari Pediatri 2009;11:189-98.

13. Chirande L, Charwe D, Mbwana H, dkk. Determinants of stunting and severe stunting among under-fives in Tanzania : evidence from the 2010 cross-sectional household survey. BMC Pediatr 2015;15:1-13.

14. Bebars GM, Afifi MF, Mahrous DM, dkk. Assessment of some micronutrients serum levels in children with severe acute 
malnutrition with and without cerebral palsy- A follow up case control study. Clin Nutr Exp 2019;23:34-43.

15. Titaley CR, Ariawan I, Hapsari D, Muasyaroh A, Dibley MJ. Determinants of the stunting of children under two years old in Indonesia: A multilevel analysis of the 2013 Indonesia basic health survey. Nutrients 2019;11:1106.

16. Soekatri MYE, Sandjaja S, Syauqy A. Stunting was associated with reported morbidity, parental education and socioeconomic status in 0.5-12-year-old Indonesian children. Int J Environ Res Pub Health 2020;17:1-9.

17. Deshmukh PR, Sinha N, Dongre AR. Social determinants of stunting in rural area of Wardha, Central India. Med J Armed Forces India . 2013;69:213-7.

18. Nasikhah R, Margawati A. Faktor risiko kejadian stunting pada balita usia 24 - 36 bulan di kecamatan semarang timur. J Nutr Coll 2012;1:176-84.

19. Çelikkiran S, Bozkurt H, Coşkun M. Denver developmental test findings and their relationship with sociodemographic variables in a large community sample of 0-4-year-old children. Arch Neuropsychiatr 2015;52:180-4.

20. Septiawahyuni HD, Suminar DR. Kecukupan asupan zinc berhubungan dengan perkembangan motorik pada balita stunting dan non-stunting. Amerta Nutr 2019;1-6.

21. Susanty NM, Margawati A. Hubungan antara derajat stunting, asupan zat gizi dan sosial ekonomi rumah tangga dengan perkembangan motorik anak usia $24-36$ bulan di wilayah kerja Puskesmas Bugangan. J Nutr Food Sci 2012;1:327-36.

22. Adani FY, Nindya TS. Perbedaan asupan energi, protein, zink, dan perkembangan pada balita stunting dan non stunting. J Unair 2017;1:46-51.
23. Grantham-McGregor S, Cheung YB, Cueto S, Glewwe P, Richter L, Strupp B. Developmental potential in the first 5 years for children in developing countries. Lancet 2007;369:60-70.

24. Rahmaniah. Riwayat asupan energi dan protein sebagai faktor risiko stunting pada anak usia 6-23 bulan di Kecamatan Sedayu Kabupaten Bantul - tesis. Yogyakarta: Universitas Gadjah Mada, 2014.

25. Azmy U, Mundiastuti L. Konsumsi zat gizi pada balita stunting dan non-stunting di Kabupaten Bangkalan. Amerta Nutr 2018;2:292-8.

26. Losong NHF, Adriani M. Perbedaan kadar hemoglobin, asupan zat besi, dan zinc pada balita stunting dan non stunting. Amerta Nutr 2017;1:117.

27. Sumedi E, Sandjaja. Asupan zat besi, vitamin A dan zink anak Indonesia umur 6 - 23 bulan. Penelit Gizi dan Makanan 2015;38:167-75.

28. Soemantri A. Epidemiologi of iron deficiency anemia. Dalam: Rina Triasih, penyunting. Anemia defisiensi besi. Yogyakarta: Medika Fakultas Kedokteran UGM; 2005.h.8-25.

29. Hermoso M, Vucic V, Vollhardt C, dkk. The effect of iron on cognitive development and function in infants, children and adolescents: A systematic review. Ann Nutr Metab 2011;59:154-65.

30. Lunn PG. Growth retardation and stunting of children in developing countries. Br J Nutr 2002;88:109-10.

31. Cusick SE, Georgieff MK, Rao R. Approaches for reducing the risk of early-life iron deficiency-induced brain dysfunction in children. Nutrients 2018;10:1-14. 